\title{
Al-Quran Based Learning Strategy in Teaching Mathematics at Primary Education
}

\author{
Mansur \\ Elementary School Teaching Learning \\ Universitas Negeri Padang \\ mansur@fip.unp.ac.id
}

\author{
Yullys Helsa \\ Elementary School Teaching Learning \\ Universitas Negeri Padang \\ yullys@fip.unp.ac.id
}

\author{
Ary Kiswanto Kenedi \\ Elementary School Teaching Learning \\ Universitas Negeri Padang \\ arykenedi@gmail.com
}

\begin{abstract}
The Qur'an is our sacred to the Muslims. The Qur'an is used as a guide of life for Muslims around the world. Many lessons are learned from the Alquran. Including elementary school learning is no exception to mathematics learning. This study aims to develop mathematics teaching materials that integrate the concept of the Alquran in learning mathematics in elementary schools. The type of research is research and development. The research subjects were SDN 12 Padang Panjang city and MIS Unggul Padang Panjang city. The research instruments are evaluation sheets and observation sheets. The results of the study there is a significant improvement on the results of learning cognitive mathematics, affective and psychomotor.
\end{abstract}

Keywords-alquran; mathematics learning, low class, elementary school.

\section{INTRODUCTION}

AlQuran is a treatise and a proof of the apostleship and prophet hood of Muhammad SAW to conquer who has denied and denying the truth [1]. But for those who believe, it says that the Qur'an is not a miracle but a hint (hudan or al-nuur). That is, for someone who has faith and who has knowledge, then the higher chance for him to explore the science that is in Al-Qur'an. And also for those who believe in Al-Qur'an will open the opportunity for him to enter the secret of Al-Qur'an in science. Al-Qur'an greatly upholds the occupation of science and this, in the context of the exposure to science we will never find in other scriptures. And this we seen proof, AlQur'an given nature to the nation of Arabia in the days before Islam came with the name of the period of ignorance.

This can be found in Al-Qur'an which states that Al-Quran strongly supports humans to see yhe science. In Surah Al Mujadillah (Q.S 58:11) Allah said it means: ... and when it is said; 'Stand ye', then stand, Allah will exalt those who believe among you and those who are given knowledge of some degree. And Allah is omniscient of what you do". The purpose of the verse is that Allah rewarded gaping Allah SWT lifting the believers to unbelievers some degree of height, and Allah SWT appoints believers and knowledgeable knowledge of the believers but knowledgeable of some degree the height. In short Allah Almighty exalts the dying of the believers, especially the believers with knowledge.

Furthermore Allah says in Surah Az - Zumar (QS 39: 9) means: Are you a more lucky polytheist) or worshiped at night by prostration and standing, while he is afraid of the Hereafter and expects grace Her God? Say: "Are there those who know with those who do not know?" Indeed, people who baraqallah who can receive lessons. The purpose of this verse is that Allah affirms that the knowledgeable man is the one who can receive the lesson. Al-Qur'an invites people to seek knowledge and invite other human beings who have not sought knowledge to think cause and effect, observant and take the truth from a conclusion. Al-Qur'an mentions people to seek knowledge by doing research, observer for themselves and for the natural surroundings, to believe in causal relationships.

Many scientists have proved Al-Qur'an as a source of life, guidance, and life guidelines. In fact all that exists in this world basically refers to the holy book of Al-Quran. Because the holy book that was revealed to the Prophet Muhammad has summarized all the previous books. The point is that in AlQur'an there are many sciences that can be useful as human life.

Mathematics is a universal science that underlies the development of modern technology. Rapid development in the field of technology and information at this time is also based on the development of mathematics in various fields. To master and deepen the technology in the future, it takes the mastery of mathematics from an early age. Therefore, mathematics becomes one of the subjects that must be mastered by kindergarten up to university. This is no exception at the level after elementary school.

In general, the purpose of learning in primary schools is to enable students to be skilled in using mathematics. In particular the objectives of learning mathematics in elementary schools [3] as follows: (1) Understand the concepts of mathematics, explain the interconnectedness of concepts, and apply concepts or algorithms; (2) Using reasoning on patterns and traits, performing mathematical manipulations in generalizations, compiling evidence, or explaining mathematical ideas and statements; (3) Solve problems that include the ability to understand problems, design mathematical models, complete the model, and interpret the solutions obtained; (4) Communicate ideas with symbols, tables, diagrams, or other media to explain the situation or problem; and (5) Have an appreciative attitude to the use of mathematics in everyday life. 
The point is that the purpose of learning mathematics so that learners understanded the mathematical concepts, using the ability to think high level, able to communicate well, and have a mathematical attitude. To be able to realize the purpose of learning, the teacher as a form of mindset learners in the classroom, then a teacher must create conditions and learning situations that enable students to actively shape, find, and develop the science. One way teachers create enjoyable learning is that teachers should be able to present effective learning materials.

"In addition, the effectiveness of the modules was tested and it was found that the module was effective for visual learners, active learners and reflective learners" [4], the point is that in addition, once tested the effectiveness of the module found that the module is very effective used by students who are visual, active students and students are relektif. This is in line with the research conducted by [5] states that "The results of the survey show that the students consider the course contents of the Math module in the foundation program offered in Majan College to be very effective. A similar study can be recommended on students to improve the effectiveness by adopting various strategies for teaching and learning mathematics."

The point is that the results of the survey show that students studying with the learning module at Majan College are very effective in the learning process. And it is highly recommended for students to be able to use learning modules to improve the effectiveness of learning by adopting a mathematical learning strategy. Mathematics learning is still a frightening specter for students. This classical problem still continues to be a major problem in the process of learning mathematics. This is due to the inability of teachers to create an atmosphere of learning that can make students make learning fun.

\section{METHOD}

The research method is qualitative descriptive. Data collected through observation and interviews conducted on the respondents namely teachers of early childhood education in the city of Padang. Respondents were taken by purposive sampling is some Early Childhood Education institutions located in North Padang Sub district which is UNP assisted institution. Data were analyzed using Miles and Huberman analysis technique

Based on the research objectives that have been designed, then this type of research is research development or Development Research. The development model used is the ADDIE model. "ADDIE model is one of the most common models used in the instructional design field a guide to producing an effective design. This is an ADDIE model on any instructional product [6]." The meaning is that the ADDIE model is one of the most common models used in instructional design to produce productive designs. This model is an approach that helps the instructional developer, the instructional developer, or even the teacher to create an efficient, effective teaching design by applying the ADDIE model process to each instructional product.

\section{RESULT AND DISCUSSION}

The purpose of this development stage produced a valid $1 \mathrm{st}$ and 2nd grade Al-Quran based mathematics teaching material that is suitable for use in the learning process. This development stage consists of two stages, namely: validation and practice test. Stage of effectiveness test is not done because the researcher has limited in terms of cost, time and energy.

The developed teaching material is then validated by the validator. Validation is done by three validators who work as lecturers in universities. In this activity the validator is asked to assess the teaching materials that have been made. This assessment includes the feasibility of the content of teaching materials, language and readability and presentation. The validator is required to provide an assessment and suggestion on the material that has been developed.

Based on the results of discussions and suggestions and input from the validator revision of teaching materials mathematics materials based on Al-Qur'an in 1 st and 2nd grade's class. Once recapitulated, the things that should be revised for both learning are the same. So the suggestions of the validator are recorded in a single table.

The revised 1st and 2nd grade Al Quran based mathematics lessons were handed back to the validator. The validator is required to provide an assessment and opinion on the instructional material that has been designed and revised according to the input of the validator. Further validator states that the instructional material that is designed is valid and ready for trial.

Validation of teaching materials is done on several aspects, namely the feasibility of the content of teaching materials, language and legibility and presentation. The validation results of each aspect will be described in detail for each lesson, as follows:

1. Learning Numerical Material

Mathematics materials based on Al-Quran in 1 st and 2 nd class in teaching material validated by the validator. Validation results will be described in detail in each aspect.

In QS. 18:25 is the number 300 units siniin (plural of sanah word). In Arabic, the word "sanah" is mu'annats, while the word "amm" is mudzakkar. In QS. 18: 25, the number 9 is expressed with the word "tis'a" mudzakkar not with the word "tis'a" refers to know Qamariyah ('aam is mudzakkar). So QS. $18: 25$, as if there is a sum with a different unit that is

$$
300 \text { sanah + } 9 \text { 'aam. }
$$

The true meaning of the QS. 18:25 is Ashabul Kahfi living in a cave for 300 years Syamsiah. If 300 years of this Syamsiyah want to be the year of Qamariyah, then equal to 309 years of Qamariyah. This is based on the following calculations. 
2. Geometry

Consider the shape of the solar system, notice the shape of the sun, the moon, the earth and the planets are all spherical. Notice the shape of the earth's path around the sun, as do the paths of other planets around the sun, all elliptical in shape. If we look at the Qur'an, some 600 years before, the Qur'an has declared that everything is created mathematically. Notice the word of God in the Qur'an Al-Qamar verse 49 verse follows: We created everything by measure.

Notice also the Qur'an letter Al-Furqaan verse 2:

His possession is the kingdom of the heavens and the earth, and he has no son, and no partner is in his power, and he has created all things, and he sets his measurements to the same degree. From the above two verses it is explained that, Allah created the universe and all its contents with its sizes and its neatly. Everything created has a predetermined shape and size. Next, we discuss about the types or forms of wake-up space.

Table 1. Result of Material Validation for the Feasibility Aspect of Content

\begin{tabular}{|c|l|c|c|}
\hline No & Aspects rated & Average & Category \\
\hline 1. & $\begin{array}{l}\text { Conformity of the material to the } \\
\text { curriculum }\end{array}$ & 3.33 & Valid \\
\hline 2. & The truth of the concept can be accounted & 3.33 & Valid \\
\hline 3. & $\begin{array}{l}\text { The description of the material is } \\
\text { complete and clear in accordance with the } \\
\text { learning of mathematics based on Al- } \\
\text { Quran }\end{array}$ & 3 & Valid \\
\hline 4. & $\begin{array}{l}\text { Presenting materials in accordance with } \\
\text { the development of learners }\end{array}$ & 3.33 & Valid \\
\hline 1. & $\begin{array}{l}\text { Displays tables or schemes or drawings to } \\
\text { explain the concept }\end{array}$ & 3.66 & $\begin{array}{l}\text { Very } \\
\text { Valid }\end{array}$ \\
\hline 6. & $\begin{array}{l}\text { Increase the insight of learners, especially } \\
\text { in finding the contextual problem and } \\
\text { solve the problem }\end{array}$ & 4 & $\begin{array}{l}\text { Very } \\
\text { Valid }\end{array}$ \\
\hline
\end{tabular}

Based on the presentation in table 1 which shows the average value in the above statement is a partial statement has an average of 3 and 3.33 are in the category of valid and some have an average of 3.66 and 4 are located in the category is very valid. For the overall average of the content feasibility aspect is 3.44 which is in the valid category. This means that the content of teaching materials has shown the suitability between the content with $\mathrm{KI}$ and $\mathrm{KD}$, with the objectives of the learning and indicators formulated, the material has been in accordance with the stages of Al-Qur'an based Learning Mathematics as well as in accordance with the development of learners.

\section{CONCLUSION}

The development of learning materials of mathematics based on Al-Qur'an in 1 st and 2 nd class semester 1 is valid in the view of the validators. The result of validation of learning is 3.44 which is in valid category. Based on the results of the research that has been proposed, it can be suggested that it can develop teaching materials based on Al-Quran Learning Mathematics is further on a wider scope with different situations and conditions to get more perfect results.

\section{Acknowledgment}

Authors would like to thank all those who contributed to completion of this article. Thanks also to the research fund provider, Universitas Negeri Padang.

\section{References}

[1] Basya, Fahmi. 2007. Matematika Islam Sebuah Pendekatan Untuk Yakin. Jakarta: Republika.

[2] Basri, Tabrani. 2010. Keampuhan Al Qur'an Banyak Dibuktikan Ilmuwan. Nuonlne: Jakarta.

[3] Susanto, Ahmad. 2013. Teori Belajar dan Pembelajaran di Sekolah Dasar.Jakarta: Kencana Prenada Media Group.

[4] Alias, Norlidah.2012. Design And Development Of Physics Module Based On Learning Style And Appropriate Technology By Employing Isman Instructional Design Model. TOJET: The Turkish Online Journal of Educational Technology - October 2012, Volume 11 Issue 4.

[5] Dalal Al Nasseri. Effectiveness of Mathematics Module in Foundation Programme in Majan College Sonal Devesh1. International Journal of Emerging Engineering Research and Technology. Volume. 2, Issue 1, April 2014, PP 1-7.

[6] Aldoobie, Nada. 2015. ADDIE Model. American International Journal of Contemporary Research. Vol. 5, No. 6; December 2015. 